\title{
TOWARDS A METAPRAGMATIC DESCRIPTION OF IDIOM MEANING*
}

\author{
HACIA LA DESCRIPCIÓN METAPRAGMÁTICA DEL \\ SIGNIFICADO LOCUCIONAL
}

\author{
LARISSA TIMOFEEVA \\ University of Alicante, Alicante, España. \\ Timofeeva@ua.es
}

\begin{abstract}
Idioms constitute one of the most interesting and fascinating linguistic phenomena, the study of which continues to bring new findings from different theoretical and applied perspectives. This paper aims to provide a comprehensive approach to idiom meaning conceived as an eminently pragmatic matter with some idiosyncratic traits (Dobrovol'skij \& Piirainen, 2005; Timofeeva-Timofeev, 2012). For this reason, the focus adopted is a metalinguistic reflection (Verschueren, 1999; 2000) on the communicative role of idioms. This general framework leads us to propose a two-level metapragmatic idiom meaning model, whose purpose is to systematically depict the discursive behavior of idioms according to their inherent semantic complexity (cfr. Telija, 1996; Timofeeva-Timofeev, 2012). Such an approach can prove useful in a variety of applied fields including, amongst others, translation studies, foreign language learning and teaching, figurative language acquisition and clinical linguistics.
\end{abstract}

Keywords: Idiom, figurativity, metapragmatics, two-level idiom meaning model.

\section{RESUMEN}

El estudio de las locuciones -y de las unidades fraseológicas en general- sigue suscitando un gran interés, tanto desde la perspectiva teórica como desde los diversos ámbitos aplicados. Este trabajo busca ofrecer un acercamiento teórico coherente al análisis del significado locucional, enfocado este desde su naturaleza inherentemente pragmática, pero

* This paper is part of the ongoing research projects The Development of Figurative Awareness during the Primary School Period: Humor and Phraseology (FFI2016-76047-P, AEI-FEDER/EU) and Metapragmatics of Children's Humor: Acquisition, Gender Perspective and Applications (GRE14-19, University of Alicante). I would also like to acknowledge Leonor Ruiz-Gurillo for her helpful and insightful comments. 
con características idiosincrásicas (Dobrovol'skij \& Piirainen, 2005; Timofeeva-Timofeev, 2012). Por ello, la cuestión se plantea como una reflexión metalingüística (Verschueren, $1999 ; 2000)$ en torno al papel comunicativo de las locuciones. Tal marco general nos lleva a proponer un modelo metapragmático del significado locucional en dos niveles cuyo propósito es la sistematización de la descripción del comportamiento discursivo de las locuciones atendiendo a su complejidad semántica (cfr. Telija, 1996; Timofeeva-Timofeev, 2012). El modelo propuesto puede resultar útil en su aplicación a diversos ámbitos, tales como la traductología, la enseñanza de lenguas, la adquisición del lenguaje figurado o la lingüística clínica, entre otros.

Palabras clave: Locución, figuratividad, metapragmática, modelo del significado locucional en dos niveles.

Recibido: 18.01.2017. Aceptado: 18.10.2017.

\section{INTRODUCTION}

The study of idioms, one of the most interesting and fascinating linguistic phenomena, still offers a wide range of theoretical as well as applied findings. Analyzing the acquisition and cognitive processing of idioms reveals not only their greater complexity compared to other lexical samples but also their higher communicative effectiveness. These aspects have been addressed by scholars from different theoretical positions. Vinogradov's (1947) very early phraseologically bound meaning, Pawley \& Syder's (1983) later conception of formulaicity as a core of nativelike linguistic fluency, and Sinclair's (1991) idiom principle, all evidence the researchers' endeavor to come up with an appropriate framework reflecting both phraseological pervasiveness in our communication and its inherent specificity. More recently, Wray's $(2002,2008)$ conception of fomulaicity as a linguistic tool to share our emotional, physical and mental states adds an empathetic dimension to the phenomenon under examination, which broadens the range of information an idiom may deploy in use. Notwithstanding all these focal points, there are no systematic approaches to the sort of data engaged in the idiom meaning configuration.

The body of research concerning idiom processing currently shapes AngloSaxon phraseological tradition, of which the three theoretical standpoints cited above are representative. European phraseology, on the other hand-essentially stemming from the Russian lexicography school inherited from Vinogradov- traditionally focuses on cross-linguistic analysis with special attention paid to the cultural basis of the formulaicity (cfr. Omazić, 2005a: 1-2). In this context, bringing together findings from both traditions becomes a research challenge that can offer important applied outcomes. 
Such an 'inter-theoretical' approach is needed to examine inside the idiom meaning. Determining the 'pieces' of its complexity, we will be able to undertake a systematic metalinguistic reflection in order to understand the motives as to why speakers more or less consciously resort to idioms. Identification and depiction of general patterns guiding idiom use would imply significant advances in applied fields such as translation studies, foreign language learning and teaching, figurative language acquisition and clinical linguistics.

Curiously, as we point out above, little attention has been given to the analysis of types of knowledge by which the idiom meaning is articulated. In Russian tradition, Telija (Telija et al., 1990; Telija, 1996), in a rather isolated attempt, proposed her macro-componential model of phraseological meaning in order to guide the metalinguistic approach to the matter. Nonetheless, Telija's proposal does not reflect the inherently pragmatic nature of idiom meaning, nor does it explain idioms' behavior inside an utterance. The pragmatic condition of these items, however, is widely recognized; accordingly, reflection on how their meaning is articulated should be of a metapragmatic kind.

This paper seeks to provide a comprehensive theoretical approach to idiom meaning conceived as an eminently pragmatic matter with a number of idiosyncratic traits. A two-level metapragmatic idiom meaning model is proposed within this general framework, which aims to systematically depict the communicative nature of idioms along with their discursive behavior depending on their inherent semantic complexity. Our proposal mainly adheres to the European phraseological school with special attention to recent Russian and Spanish contributions. Moreover, these new developments are interwoven into a wider theoretical framework of metapragmatic reflection on language use, which allows us to systematize the metapragmatic approach to idiom meaning.

As for the way in which our paper is structured, Section 2 below offers a short review of the theoretical mainstays, after which Section 3 focuses on the presentation and explanation of the two-level idiom meaning model, which constitutes an attempt to embrace the specific semantic and pragmatic features that characterize this linguistic phenomenon. The study ends with a summary of our main conclusions offered in Section 4.

\section{THEORETICAL CLUES}

It is proposed essentially rests on two theoretical pillars. The first one deals with idioms understood as figurative language samples with several idiosyncratic features. The second has to do with the metapragmatic perspective adopted as our main methodological framework. The key aspects of both pillars are briefly outlined below. 


\subsection{Idioms: What are they?}

The most common definition of idioms regards them as multi-word strings, the whole meaning of which is holistic in nature; in other words, "the meaning of the whole phrase is not understood in terms of the meanings of its individual parts; rather, all of them contribute to its configuration" (Timofeeva-Timofeev \& Vargas-Sierra, 2015: 109). It should be pointed out that such a conception of holism does not preclude a certain degree of analyzibility in processing idioms, which is in line with other researchers' claims (cfr. Siyanova-Chanturia, 2015; SiyanovaChanturia \& Martínez, 2015: 558-560). Such a holistic meaning may be totally or partially figurative, which means that it complies with two basic requirements of figurativity (Dobrovol'skij and Piirainen, 2005: 5 passim), namely: additional naming and the image component.

The first criterion, additional naming, draws attention to the fact that idioms appear as an alternative way of referring to a concept. Expressed in a straightforward way, other lexical items conveying the same in semantic terms exist that fulfill the primary denomination function. By way of example, English provides the lexeme expensive as a primary denomination to describe something that "costs a lot of money or entails great expense" (cfr. RHWD, 2001). Concurrently, saying that something costs an arm and a leg basically conveys the same meaning as it is expensive. Another example: the idea that doing something requires no effort is primarily expressed by the lexeme easy, even though a number of additional idiomatic resources, such as a piece of cake, like taking candy from a baby or like shooting fish in a barrel, appear as alternative forms to transmit the same basic meaning.

The existence of two lexical forms which are completely equivalent in terms of meaning does not seem practical, though. The explanation of such an alternative denomination lies in the fact that it is constructed by adding semantic nuances which allow it to convey more information in a rather compact way, thus enriching the whole semantic result and making it become inherently connotative. In other words, within the semantic continuum between the denotative pole and the connotative one, idioms always tend to the latter, since their meaning not only identifies but also qualifies the referent at all times. This holds true even when the referent is single (Dobrovol'skij, 1990: 51; Timofeeva-Timofeev, 2012: 207-208), as happens, for instance, in Knight of the Woeful Countenance -Don Quixote's epithet in English. Indeed, the idiomatic denomination contains a qualitative description that provides an almost visual picture of this literary character.

Such semantic 'capital' has to do with the second requirement of figurativity, i.e. the image component which, according to Dobrovol'skij and Piirainen (2005: 14 ), basically refers to the cognitive 'bridge' emerging between the literal form of an idiom and its conventional meaning. In other words, it is the motivational 'tie' that makes an idiom meaningful for the speakers and drives him/her to prefer the 
idiomatic form over the simple lexeme. No need exists for a kind of visual image (as in the Knight of the Woeful Countenance example), but it constitutes an associative picture that may sometimes adopt rather subjective forms. For instance, an idiom is likely to evoke a particular person who uses it frequently or even the first time that the speaker heard the idiom in question and correctly inferred its meaning. In any case, once an idiom is accessed, comprehended and assimilated, it becomes motivated for the speaker, even if such motivation is unique and personal.

Dobrovol'skij and Piirainen describe the image component as a key notion that makes it possible to distinguish "figurative units from non-figurative ones" (Dobrovol'skij and Piirainen, 2005: 14). A metalinguistic approach to the image component reveals that it is supported by different sorts of knowledge often blend$e d$ in a complex amalgam as a result of the diachronic evolution of the idiom and its synchronic behavior (cfr. Omazić, 2005b). Furthermore, although the image component may have rather individual features, the analysis of frequently used albeit semantically 'opaque'-idioms demonstrates that speakers 'build' fairly similar motivational links (Timofeeva-Timofeev, in preparation) which occasionally result in a re-motivation of the meaning. For instance, the Spanish idiom a trancas $y$ barrancas (lit. approx. "by bars and ravines') meaning "with many difficulties" (cfr. DFDEA, 2004) seems to originate in an image component based on the conception of bars and ravines as metaphors of obstacles and difficulties. Nevertheless, quite a few Spanish youngsters currently associate this idiom with the TV show El hormiguero broadcast on the Spanish Antena 3 channel. The two puppet ants Trancas and Barrancas form part of this program's 'team' of fictional characters. The popularity of these two puppets, whose role in the show is a comical one, has caused a re-motivation of the idiom a trancas y barrancas, as a result of which its original meaning is undergoing certain semantic changes. As a matter of fact, one of our previous studies (Timofeeva-Timofeev, in preparation) confirmed that the meaning of this idiom is now "in a crazy, zany way" for most young speakers.

The image component requirement also explains the holistic nature of idiom meaning, whereby the string's meaning as a whole is not understood to be the result of the addition of the meanings of each individual lexeme, though all of them contribute to configure the global unified meaning. According to this,

[I]t is possible to analyze the contribution of each constituent to the whole meaning, but we can neither predict nor calculate the semantic result from the individual meanings of the constituents. In other words, being aware of the denotative meaning of a figurative unit enables us to establish and understand the cognitive links that support the image component; however, it is not always possible to 'reconstruct' the whole figurative meaning only from the features of the image component (Timofeeva-Timofeev \& Vargas-Sierra, 2015: 109). 
The image component plays a decisive role in the pragmatic adjustment of an idiom, since its features delineate the choice amongst semantically similar items in a specific context ${ }^{1}$. For example, the use of the Russian idiom старая дева 'staraja deva' (lit. 'old virgin'), which usually translates into English as 'spinster' or 'old maid' (cfr. BRAFS, 2004), has contextual restrictions due to the image component. Старая дева evokes some implied information, including a certain age threshold (which can change to a greater extent from a social point of view) or the involuntary nature of the fact of being unmarried, related, hence, to the concept of 'failure'. That is to say, this Russian idiom could not be used to refer to a convinced single woman with an active sexual life, unless other discursive effects (e.g. irony or humor) are pursued. Another example of an image component restriction can be found in the Spanish idiom no estar muy católico (lit. 'not to be very Catholic') meaning "to not feel very well" (cfr. DFDEA, 2004). The mere allusion to the Catholic faith 'prevents' this idiom from being used in contexts referring to other religions, once again with the exception of contexts where the speaker pursues a different pragmatic intention.

It thus becomes obvious that all these additional semantic data appear as implied information or, to put it in another way, they result from the diachronic evolution of initially pragmatic inferences. Idiomatic meaning hence becomes a good example of what Levinson (2000) calls pragmatic intrusion into semantics, even though the degree of conventionalization found in these implicatures varies from one idiom to another (see Section 3.3. below).

Such implied knowledge not only underpins the meaning of idioms but also explains their communicative frequency and efficiency despite being alternative denomination units. Furthermore, carrying out a systematic description of all such data will surely provide us with patterns for a metalinguistic -and more specifically, metapragmatic- reflection on the role played by idioms in discourse.

\subsection{Metapragmatic keys of language communication}

The previously highlighted conception of figurativity makes it clear that the use of idioms in discourse derives from a more or less conscious choice-making process. As explained above, idioms usually belong to an 'inventory' of lexical resources available to express (almost) the same basic meaning. Therefore, any decision made by speakers to draw on an idiomatic procedure presupposes a certain degree of awareness that leads them to adapt such decision to a specific set of contextual

${ }^{1}$ For instance, Dobrovol'skij and Piirainen (2005: 15) analyze the extent to which the image component features of the idiom to be between a rock and a hard place determine its context of use. 
circumstances. That is to say, the simple fact that idioms represent an alternative way to refer to a concept (the additional naming criterion) implies a higher level of discourse control and thus a more reflexive use.

Describing the nature of idioms in this way leads us into the broader issue of metapragmatic monitoring of discourse. After all, speakers undoubtedly know -though with various degrees of awareness- what they are doing when they use language (Verschueren, 1999: 187)2. Along the same lines, Gombert (1992: 94) claims that while "pragmatic abilities permit the effective use of language in its (social) context, [...] metapragmatic abilities allow the comprehension and control of this use". That is to say, metapragmatically competent language users (e.g. any average native adult speaker) can not only check and adapt their discourse to the context but also clearly explain their pragmatic decisions if necessary.

Such a conception of metapragmatics nonetheless turns out to be too wide (cfr. Verschueren, 2000: 445; Timofeeva-Timofeev, 2016) insofar as language use inevitably entails awareness to some extent. In Verschueren's words,

Reflexive awareness may be so central that it could be regarded as one of the original evolutionary prerequisites for the development of language. It is so central, furthermore, that all verbal communication is self-referential to a certain degree. In other words, there is no language use without a constant calibration between pragmatic and metapragmatic functioning (Verschueren 1999: 188. Italics in the original).

Therefore, a thorough linguistic approach to the notion of metapragmatics needs to rely on more identifiable elements, an analysis of which will show us the ways in which the choice-making process occurs. The domain of metapragmatics should consequently be conceived with regard to " $t]$ he systematic study of the metalevel, where indicators of reflexive awareness are to be found in the actual choice-making that constitutes language use" (Verschueren, 1999: 188).

This systematic study of metapragmatic level rests, according to Verschueren (1999: 55-71), on three hierarchically related key notions, namely: variability, negotiability and adaptability. All three of them are inseparably related and together give shape to a comprehensive access to the complex phenomenon of language communication. Even though adaptability is presented as a higher-order notion, it acts as a merely methodological tool, since adaptability "has no content without both variability and negotiability" (Verschueren, 1999: 62).

In the light of such a conception, variability concerns the range of linguistic

${ }^{2}$ This idea is not new, of course. Hockett (1960) reflects on this through the trait of total feed$b a c k$, the definition of which alludes to speakers' ability to control and freely modify their speech, in his well-known "design features of language". 
alternatives available for language users -both for the speaker and for the listenerfrom which their productive and interpretative choices can be made. This 'set' of possibilities is actually changeable and not static at all, insofar as users know that different (extra-)linguistic 'forces' may exist which could expand or reduce the variety of choices in each context.

Idioms, which are the focus of interest in this work, can largely help us understand this property of language. As pointed out earlier, idioms constitute an alternative or secondary way to denote a concept (the additional naming criterion) and therefore they appear by definition as one of the variety of options available together with primary denotative lexemes. The question that needs to be posed is thus: What drives a language user to choose an idiom rather than a simple lexeme?

This question takes us to the second key notion when it comes to metapragmatic awareness: negotiability. According to Verschueren (1999: 59-61), this characteristic of language has to do with a variety of principles and strategies put into practice during the choice-making process. It is claimed that such principles are highly moldable and flexible and also that no fixed rules exist that need to be followed in the communicative negotiation process. As a result of this, the fact of being constrained -in the same way as variability- by the speaker's or the listener's communicative circumstances makes the property of negotiability undetermined in various senses. Even after having been made, choices do not remain static and "can be permanently renegotiated" (Verschueren, 1999: 61).

Seen from that point of view, idioms are tools which users utilize to shape their communication. Therefore, two research questions need to be raised: (a) When does a speaker decide to draw on an idiom? and (b) What are the semantic and pragmatic data that a listener accesses when faced with an idiom?

The property of adaptability, which completes this triadic conception, refers to the fact that both variability and negotiability are aimed at achieving the highest possible level of satisfaction for communicative needs (Verschueren, 1999: 6165). Adaptability, however, should not be seen as the adaptation to the contextual circumstances, but rather as a bidirectional process whereby linguistic choices are selected, negotiated and adapted to the context; and that same context concurrently accommodates and hence changes according to the linguistic choices made. Verschueren (1999: 62) illustrates this with the "systems of politeness which are shaped by and simultaneously shape social relationships".

Applying this reasoning to idiomatic procedures, it seems to be rewarding to analyze not only the communicative impact that the decision to use an idiom instead of a simple lexeme may have, but also the extent to which idioms promote a high degree of satisfaction and meet language users' communicative needs. The next section of our paper will outline a theoretical framework for metapragmatic reflection on idiom meaning based on the ideas explained so far. 


\section{METAPRAGMATICS OF IDIOM MEANING}

As highlighted above, what makes idioms idiosyncratic and special from a linguistic point of view is their syntagmatic form correlated to a basically lexemic behavior in discourse. This peculiarity obviously has diachronic roots insofar as an idiom occurs when certain pragmatic inferences start being frequently associated with a particular multi-word combination ${ }^{3}$. These inferences are eventually embedded into the combination which functionally becomes a lexeme with a unified but multifaceted meaning.

The origin of idioms (i.e. the phraseologization process) described in diachronic terms reveals the essentially pragmatic nature of these linguistic elements (cfr. Timofeeva-Timofeev, 2012: 166-167; Sánchez-López, 2015). Metalinguistic reflection on idiom meaning thus has to be embraced under the metapragmatic 'umbrella' which enables us to specify and explicitly state the different sides of its polyhedral identity. The metapragmatic perspective adopted allows us, moreover, to construct a systematic model including a range of information that molds the conventional idiom meaning and explains some discursive effects that this meaning triggers. Hence, an effort will be made on the next pages to delineate such a comprehensive idiom meaning model based on a metapragmatic conception of the phenomenon.

Bringing together all the theoretical issues hitherto dealt with (see Sections 2.1. and 2.2. above), three connected and closely interwoven ideas underpin our proposal:

- The metapragmatic idiom meaning model should reflect the dual nature of idioms that results from their diachronic evolution. Consequently, it should be articulated on two levels of meaning according, on one hand, to the complexity of idiom semantics deriving from its polylexical structure, and on the other, to the effects of that semantic complexity on the pragmatic level (in other words, when the idiom is included in an utterance where it becomes a functional lexeme).

- An idiom meaning model should display the figurative attributes of idioms, or more precisely, the two figurative criteria: additional naming and the image component.

- Finally, this model should stress the importance of systematic metapragmatic reflection patterns related to the features of variability, negotiability and adaptability.

${ }^{3}$ This point of view is actually in keeping with the functionalism of Coseriu (1986) or $\mathrm{Zu}$ luaga (1980). It is widely accepted that idioms are functional -albeit idiosyncratic- lexemes. The point is to find out, depict and systematize that idiosyncrasy. The metapragmatic approach adopted in this study provides us with an adequate framework to tackle these research issues. 


\subsection{First level: semantics of idiom meaning}

As pointed out above, idioms are syntagmatic combinations with lexemic behavior. Therefore, a metapragmatic approach to idiom meaning should regard two linguistic performance levels (semantic and pragmatic) so that this idiosyncrasy can be properly portrayed. The first one, conveniently called semantic level ${ }^{4}$ here, refers to a variety of knowledge that is interwoven in the conventional meaning of an idiom. At the second pragmatic level, the attention focuses on the degree of influence that these semantic data exert on discursive idiom performance, as well as on other kinds of inferences triggered by a multi-word lexeme within an utterance.

Let us thus start with the semantic level. For the purpose of systematically depicting an information range involved in the complex idiom semantics, Telija (Telija et al., 1990; Telija, 1996; Kabakova, 2002) proposes a macro-componential model which revolves around six informational blocks, each of which embraces one of the conventional meaning parameters: denotation, motivation, rational assessment, emotional and attitudinal assessment, stylistics and grammar. Later revised by Timofeeva-Timofeev (2008; 2012: 205-244) in Spanish, this model represents an attempt to consistently isolate and systematically describe different kinds of knowledge entwined in idiom meaning, although such 'chunking' abides by exclusively metalinguistic aims.

\subsubsection{Denotative block}

This embraces the information associated with the referent of an idiom, i.e. its denotative meaning. For example, the previously mentioned idiom to cost an arm and a leg denotes the quality of 'expensive'. The Spanish idiom cuando las ranas crien pelo (lit. 'when frogs get hair') denotes the circumstance of 'never'. Note that, despite being provided by the dictionary as a semantic meaning of the idiom, this denotative value does not actually reflect a variety of relevant nuances that complete it. In fact, such nuances provide evidence that the idiom complies with the additional naming criterion (see Section 2.1.), consequently including connotative data at all times (Timofeeva-Timofeev, 2012: 206-211). In other words, the most prominent feature in the denotative block of idiom semantics turns out to be that this linguistic element not only denotes but also connotes, which in turn explains

\footnotetext{
${ }^{4}$ Once again, the pragmatic origin of conventional idiom meaning does not enable its identification with semantics strictly speaking. This is why idioms are treated as instances of Levinson's (2000) pragmatic intrusion into semantics (see Section 2.1.) in this study. Nonetheless, and seeking to simplify the explanation, 'semantic level' will be used here to describe conventional idiom meaning, with no reference whatsoever to contextual circumstances that are of course likely to tinge, enrich or even modify such 'semantic' values.
} 
why language users choose an idiomatic string despite having other much simpler linguistic alternatives available (i.e. the property of variability). Such a choice allows them to express rather complex connotative values in a fairly compact way and to ensure their listener's comprehension (as a competent speaker) based on a shared (un-)conscious knowledge of the semantic nuances present in the meaning of an idiom.

\subsubsection{The image component or motivational block}

The source from which these connotations stem is very often the information comprised in the second block of the model, the motivational one. This block has to do with the other figurative criterion (Dobrovol'skij and Piirainen, 2005: 14), the image component (see Section 2.1. above), which appears to be a core constituent of idiom meaning insofar as it provides the motivational bond allowing language users to choose an idiom instead of a simple lexeme. As pointed out above, such a motivational bond does not necessarily have to be of a visual kind but is rather an associative 'bridge' between the lexico-semantic structure of an idiom and its conventional meaning. This association relies on a set of cultural, conceptual or etymological knowledge, normally blended (Coulson, 2001; Dancygier \& Sweetser, 2014; Fauconnier \& Turner, 1998) into an inseparable whole.

By way of example, the aforementioned idiom to cost an arm and a leg reveals a clear conceptually and culturally based image component where parts of the body such as arms and legs are presented as highly valuable items, since their loss disables people for normal life. Likewise, some users may connect this image to the issue of organ trafficking, which is becoming a lucrative business in certain parts of the world. In any case, sociocultural knowledge guides the user to establish the connection between the value of these limbs and the concept of expensiveness. As far as the Spanish idiom cuando las ranas crien pelo is concerned, an absurd image of a hairy frog obviously clashes with our cultural knowledge about the batrachians' attributes. Such incongruence allows us to link this lexico-semantic structure to the meaning of 'never'.

Notwithstanding these examples, the image component may have quite particular and personal traits (see Section 2.1.) for different users, especially when the motivational link is more opaque. This fact does not challenge the validity of our proposal, though, because the model presented seeks to determine the general axes around which idiom meaning is articulated. The image component appears to be at the core of this meaning since it supports its motivational bases and makes them comprehensible, whatever they might be for each particular language user. Therefore, motivational bonds become communicative strategies channeling the negotiation process. 


\subsubsection{Rational assessment block}

This block refers to the rational assessment 'encapsulated' in the semantic meaning of an idiom. Such an assessment is called rational because it follows logical -and hence, mostly unbiased-procedures. This allows idiom meaning to be described along two evaluative axes: quantitative and qualitative. As for quantitative information, this is distributed amongst three points of the continuum: more than the norm, the norm and less than the norm. Qualitative data are correspondingly arranged in relation to three other references: positive, indifferent and negative. For example, the idiom to cost an arm and a leg analyzed here includes the quantitative evaluation more than the norm, i.e. 'very expensive' within its meaning. As regards qualitative assessment, even though a certain inclination exists towards the negative side of the continuum (expensiveness seems not to be valued in this case) additional contextual data are needed in order to complete this kind of information. Put another way, the qualitative evaluation of meaning for this idiom will be negotiated at the second level of the model (Section 3.3.) when it eventually comes to form part of an utterance.

The Spanish idiom cuando las ranas crien pelo also comprises the quantitative evaluation of more than the norm, since the distance and impossibility associated with 'never' seem to increase to an even greater extent. However, the qualitative assessment is neutral and the idiom appears to be completely dependent on the context (i.e. the second level) when negotiating and adapting this part of its meaning.

\subsubsection{Emotional and attitudinal assessment block}

This comprises information about emotions and attitudes that speakers experience and want to transmit to their addressees through the use of an idiom. In other words, adopting Austin's (1962) terminology, both the illocutionary force of an idiom and the perlocutionary effect sought are considered in this block. Illustrating this with our example to cost an arm and a leg, the idea of extremity -and even of an effort to assume expensiveness- seems to be emphasized. The perlocutionary result pursued in the addressee may in turn range from fascination to pity, sympathy or envy. Such addressee reactions actually depend on the contextual environment where this stressed expensiveness quality will be negotiated in one way or another. What becomes definitely clear is that the user's choice of an idiom instead of a simple lexeme implies a more emotionally charged effect, especially based on image component features. The image behind the meaning of this idiom creates an empathic link -since the interlocutor has arms and legs and can 'physically' experience the degree of expensiveness- which turns out to be far more effective than the primary denotative lexeme expensive for the transmission of an emotional information range, thus ensuring a higher level of communicative 
satisfaction in keeping with the trait of adaptability.

In the case of the Spanish example cuando las ranas crien pelo, the emotional and attitudinal assessment is carried out by emphasizing the remoteness and improbability of something which speakers try to make their addressees experience. Moreover, this Spanish idiom can serve as an interesting example of a humorous phraseological item. The incongruity supporting the image component of cuando las ranas crien pelo enables this idiom to be marked as such, insofar as being incongruous may be considered the clearest criterion for the lexicographic identification of an idiom as humorous (cfr. Timofeeva-Timofeev, 2013). Humor consequently appears as one of the emotional and attitudinal evaluations occurring in the fourth block of this idiom. This fact can actually influence the negotiation and the adaptation of this linguistic choice at the second level of meaning (Section 3.3.).

\subsubsection{Stylistic block}

The focus in this block is placed on stylistic information, i. e. the register or formality scale position of an idiom. In this regard, our examples -both the English to cost an arm and a leg and the Spanish cuando las ranas crien pelo- belong to the informal register, which means that they are likely to appear in casual and less strict communicative situations. The deliberate transgression of such stylistic attributes at the second level of meaning seeks to generate additional communicative effects such as irony or humor (cfr. Timofeeva, 2009: 259-260).

\subsubsection{Grammatical block}

The grammatical features of idiom meaning are the focus of interest in this last block. Even though this kind of information was placed at the core of early structuralist typologies (cfr. Vinogradov, 1947; Casares, 1950), its interest actually lies in the relationship between the grammatical form of the phrase and the real semantic function that the idiom performs. Going back to our examples, to cost an arm and a leg is apparently a verbal idiom due to the presence of the verb cost; semantically, however, this idiom refers to the quality of being very expensive, which functionally assimilates it to an adjective. As for cuando las ranas crien pelo, this is formally a time structure oriented towards a future action, which is consistent with its functional role as an adverb. It also deserves to be mentioned that the phrase introduced by a time conjunction, cuando ['when'], alludes to a point in the future when the fact described will take place. Nonetheless, the denotative meaning reveals that the point in question does not exist. Incongruity consequently becomes visible again, in this case between the grammatical form and the denotative meaning, thus reinforcing the humorous flavor of the idiom as mentioned above. 


\subsection{Connections between the six semantic blocks}

Figure 1 graphically illustrates the componential representation of idiom semantics:

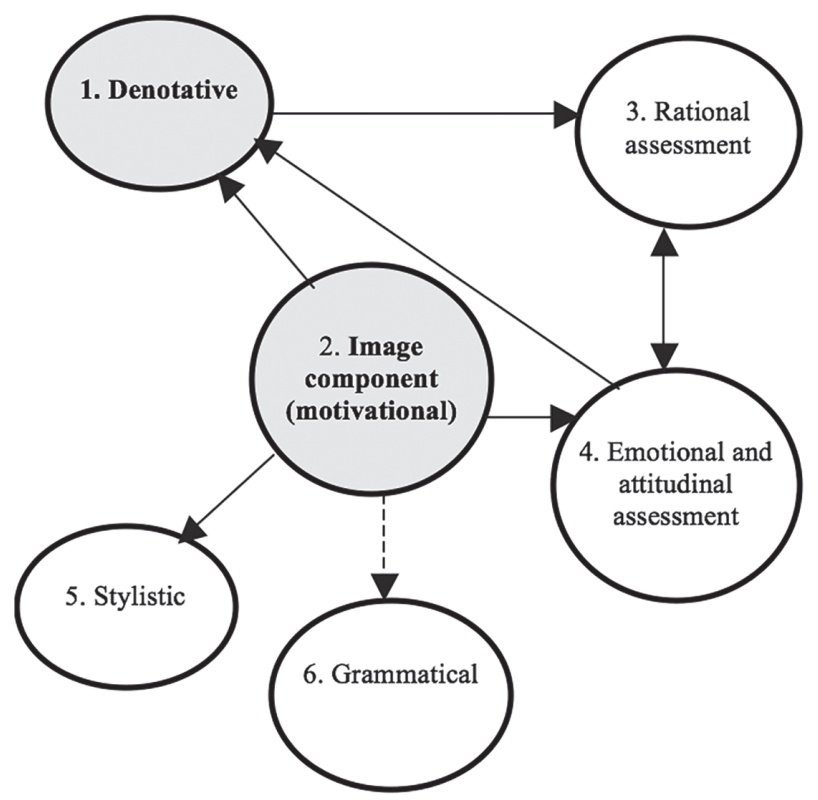

Figure 1. Semantic level of idiom meaning.

Note that the denotative and motivational blocks, which are related to the two figurative criteria (see Section 2.1.), occupy a central role in the model, acting as a starting point from which other informational blocks originate. The arrows on the graph additionally illustrate the different links between the six blocks.

The image component therefore determines the connotative nature of the denotative block, this being to 'blame' for the fact that idioms such as to cost an arm and a leg and cuando las ranas crien pelo not only denote the meaning of 'expensive' and 'never,' respectively, but also predicate and qualify the referent.

Along the same lines, the figure shows that the image component also arouses certain emotions and attitudes (the fourth block) which shape the illocutionary force of idioms. The examples analyzed demonstrate how the expression of a very high cost through a bodily experience is pursued in to cost an arm and a leg. In the case of cuando las ranas crien pelo, the emphasis on the improbability of something relies upon the absurdity of the underlying image.

The image component may exert its influence on the stylistic block, too. The presence of certain lexical items (e.g. vulgar or taboo vocabulary) in the image 
component 'building' is likely to determine its colloquial or informal assignment. Likewise, our two idioms belong to an informal register, which mostly has to do with the image supporting them.

The link between the image component and the grammatical block seems more blurred, even though a number of common patterns can actually be outlined. For example, if the image component characterizes its referent as an action, the idiom is likely to be a verb phrase. All the same, this equation does not always work. For example, as mentioned above, to cost an arm and a leg describes a quality (i.e. an adjective) despite having a verbal form, and instances like these are far from unusual.

The denotative block in turn establishes a direct link with the rational assessment when the sociocultural judgment of the denoted concept determines its rational appraisal. For example, the Russian idiom старая дева 'old maid' analyzed above (Section 2.1.) denotes a socially disadvantageous situation for a woman. This fact contributes to the intrusion of negative evaluation in the semantics of this idiom. The denotative block in the Spanish idiom puñalada trapera 'backstabbing' refers to the concept of 'treachery,' which is socioculturally rejected as well. This once more brings about the negative assessment in the third block.

The third and fourth blocks are closely interlinked too, inasmuch as the qualitative assessment in particular -whether positive or negative- evokes emotions and attitudes located along the same spectrum. However, it deserves to be taken into account that rational assessment does not always trigger emotional and attitudinal effects at this first semantic level, since quite a few idioms that include an indifferent qualitative assessment or a quantitative one require additional contextual data (i.e. the second pragmatic level) for the emotional evaluation to be developed.

In conclusion, the conception of idiom semantics presented demonstrates that relevant 'portions' of meaning have often been neglected by lexicographical approaches. Thus, while the lexicographical description of an idiom contains information of a denotative, stylistic or grammatical kind to a greater or lesser extent, the image component as well as evaluative data tend to be absent. Furthermore, this componential representation of idiom semantics highlights their pragmatic roots (i.e. phraseologization process) and points out patterns of metapragmatic reflection on the meaning of idioms.

Denotative block content is thus envisaged mainly with regard to the notion of variability as described by Verschueren (1999). In turn, the image component, rational and emotional assessments, along with stylistic features, constitute strategies and principles considered within the notion of negotiability. All together, they also explain the terms in which the characteristic of adaptability is implemented when using idioms. This leads us to address the second level of idiom meaning. 


\subsection{Second level: pragmatics of idiom meaning}

As a matter of fact, the six informational blocks that shape idiom semantics act at the same time and the itemization presented here relies exclusively on methodological premises. Furthermore, it has already been shown above that the third, fourth and fifth blocks - namely rational evaluation, emotional and attitudinal assessment and stylistic data- behave as implicatures with various degrees of conventionalization, thus matching the notion of pragmatic intrusion into semantics developed by Levinson (2000). In the light of such semantic complexity, the analysis of discursive performance of these implicatural values reveals several systematic patterns which occur when idioms become functional lexemes.

In our opinion, the degree of conventionalization found in implicatures at the first semantic level somehow determines their behavior at the second pragmatic level. In other words, when an idiom comes to form part of an utterance, it becomes a functional lexeme, but the pragmatic features of its complex semantics expand their influence on the basis of criteria that can be systematized to a certain extent.

Within the same approach, implied data with a high degree of conventionalization at the first semantic level survive at the discursive level and even impose their implicit 'load' on the whole utterance. On the other hand, implicatures which respond to the preferred way of inferring (i.e. generalized conversational implicatures understood in accordance with Levinson's conception $(1995 ; 2000))$ may be altered, modified or cancelled at this second pragmatic level.

This can be illustrated by returning to the Spanish idiom puñalada trapera ('backstabbing'), which encompasses the qualitative assessment of negative in its rational evaluative block. That value presents a very high degree of conventionalization, which is why this idiom maintains its semantic negativity -unlikely to be cancelled out by a context- inside an utterance. What is more, this negative implicature 'tinges' the whole utterance to a certain extent, since it is difficult to envision a positive context containing puñalada trapera.

Turning now to our other previous examples, the English idiom to cost an arm and a leg presents a high degree of conventionalization in its third rational quantitative assessment block: more than the norm. This condition makes such an evaluation persist at the pragmatic level and can also provide the utterance containing this idiom with a higher discursive intensity influenced by the aforementioned more than the norm implicature. The qualitative assessment, in turn, appears as a preferred, albeit less conventionalized inference. That is why the user has more communicative space to negotiate the semantics of this idiom at the second pragmatic level. Even if, as mentioned above (see Section 3.1.3.), a tendency to evaluate to cost an arm and a leg negatively may exist, the contextual environment can adapt such qualitative assessments, turning them into positive ones. In relation to this, the implicatures presented in the fourth block -emotional and attitudinal evaluation - are also less conventionalized and can consequently be 
adapted at this second level of meaning in order to meet different perlocutionary aims and achieve the highest level of communicative satisfaction (Section 3.1.4.). The stylistic information provided through the meaning of this idiom also has a rather conventionalized nature and therefore any alteration of this kind at the second level (for example, the inclusion of this idiom in a more formal or specialized discourse) seeks additional pragmatic effects, such as irony, humor, advertising goals or scientific popularization, to name but a few.

As for the Spanish idiom cuando las ranas crien pelo, it contains a highly conventionalized more than the norm implicature (quantitative assessment in the third block) and the humor attitude (fourth block), as well as a stylistically informal flavor. All these data usually remain at the second pragmatic level and give the utterance a nuance of spontaneity. However, the qualitative assessment contained in the third block needs to be developed by means of context, since no fixation exists regarding this implicature at the semantic level.

It must thus be remembered that the implicatures enclosed in diverse semantic blocks can present different degrees of conventionalization, some of them being more conventionalized than others. For this reason, the metapragmatic focus on idioms' nature adopted here does not represent them as immutable and homogeneous fixed entities, but pays attention to their internal diversity.

Together with the more or less conventionalized implicatural information inserted' into idiom semantics, these figurative items may develop purely particularized conversational implicatures, which is in keeping with their lexemic behavior at the pragmatic level. In this respect, idioms do not significantly differ from simple lexemes, and the analysis of such particularized inferences consequently falls under the domain of pragmatics.

Figure 2 graphically represents the two levels of idiom meaning:

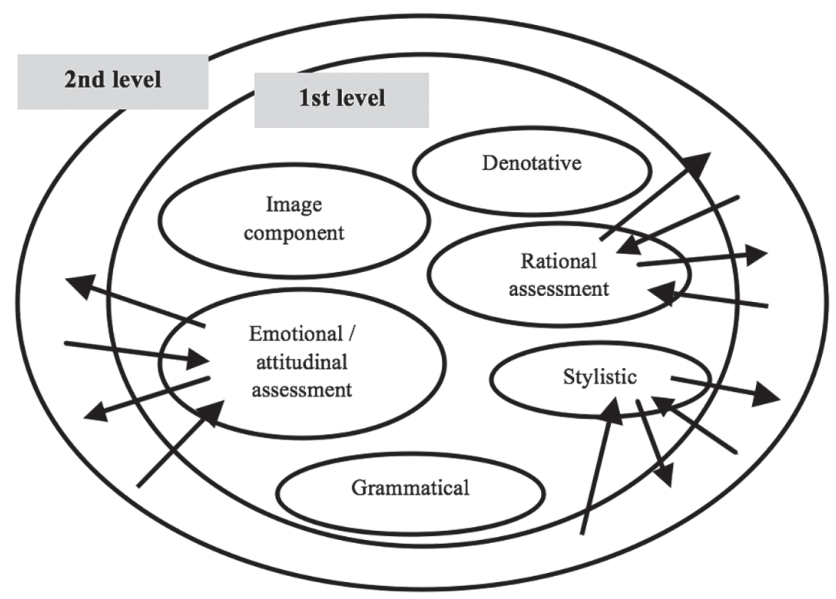

Figure 2. Two level idiom meaning model. 
The six semantic blocks (first level) appear involved in an utterance (second level) where arrows of different weight represent the bidirectional process of contextual negotiation and adaptation. The degree of conventionalization of semantic implicatures exerts an influence on the context, and concurrently the context may 'force' other additional inferences.

\section{CONCLUSIONS AND SOME NOTES FOR FURTHER RESEARCH}

The aim of this paper was to develop a methodological model for idiom meaning that could reflect the complex nature of these linguistic items. It has already been pointed out that the idiosyncrasy of idioms as phrases with a lexemic behavior can only be studied using a descriptive framework articulated around two levels of meaning: semantic and pragmatic. This conception is consistent with the diachronic evolution of idioms, the semantics of which results from integrating and conventionalizing initially pragmatic inferences.

The aforementioned framework should also display the figurative attributes (namely, the additional naming and the image component criteria) and rely on the notions of variability, negotiability and adaptability in order to account for a metapragmatic approach through which the different idiom meaning 'segments' can be explicitly stated.

The model presented here strives to embrace all these aspects. Thus, at the first level, idiom meaning is conceived as a model structured around six blocks which each explain a specific semantic parameter. The six parameters in question are: denotative meaning; motivational basis; rational assessment; emotional and attitudinal assessment; stylistic assignment; and grammatical form. All these 'portions' of rich idiom semantics derive from a diachronic evolution of initially pragmatic inferences. Furthermore, this demonstrates why language users choose an idiomatic sample despite having other linguistic alternatives available (i.e. the property of variability) and which may be the probable 'directions' of the negotiability process.

The different degrees of conventionalization shown by the implicatures present in idiom semantics determine their behavior at the second pragmatic level, i.e. when the idiom becomes a functional lexeme. The higher the degree of conventionalization identified in such implied values, the stronger their immutability and their influence at the second level of meaning. Alternatively, semantic 'segments' characterized as generalized conversational implicatures may be modified or cancelled out by the context. All these relations reveal some basic patterns of negotiability and adaptability processes and explain why idioms appear as communicatively successful linguistic elements.

Even though the idiom meaning model developed in our paper exclusively re- 
sponds to methodological reasons, evidence of its usefulness has been provided in a variety of applied fields. The artificial 'itemization' supporting this model enables us to better comprehend the choice-making process which language users have to go through in any communicative act, and also to articulate a metapragmatic reflection on the role played by idioms during that process. All these achievements will hopefully help make significant progress in the study of idioms in such varied areas as translation studies, foreign language learning and teaching, figurative language acquisition and clinical linguistics. Matters like these will be addressed in future research works.

\section{REFERENCES}

Austin, John L. [1962] (1975). How to do Things with Words (eds. J. O. Urmson \& M. Sbisà). Cambridge, Massachusetts: Harvard University Press.

BRAFS = Lubenskaja, Sofija. (2004). Bol'shoj russko-anglijskij fraseologuicheskij slovar’. Moskva: AST-Press.

Casares, Julio. (1950). Introducción a la lexicografía moderna. Madrid: CSIC.

Coseriu, Eugenio. [1977] (1986). Principios de semántica estructural. Madrid: Gredos.

Coulson, Seana. (2001). Semantic Leaps: Frame-shifting and Conceptual Blending in Meaning Construction. New York and Cambridge: Cambridge University Press.

Dancygier, Barbara \& Sweetser, Eve. (2014). Figurative Language. Cambridge: Cambridge University Press.

DFDEA = Seco, Manuel. et al. (2004). Diccionario fraseológico documentado del español actual. Madrid: Aguilar.

Dobrovol'skij, Dmitrij. (1990). Tipologuija idiom. In V. Telija et alii. (eds.). Frazeografija $v$ Masinnom fonde russkogo jazyka. Moskva: Nauka.

Dobrovol'skij, Dmitrij \& Piirainen, Elisabeth. (2005). Figurative Language: Crosscultural and Cross-linguistic Perspectives. Amsterdam: Elsevier.

Fauconnier, Gilles \& Turner, Mark. (1998). Conceptual Integration Networks. Cognitive Science 22 (2), 133-187.

Gombert, Jean É. (1992). Metalinguistic Development. New York: Wheatsheaf.

Hockett, Charles F. (1960). The Origin of Speech. Scientific American 203, 88-96.

Kabakova, Svetlana. (2002). Obraznoje osnovanije idiom. Psijolingvokulturologuicheskije aspekty. München: Otto Sagner.

Levinson, Stephen C. (1995). Three Levels of Meaning. In F. R. Palmer (ed.). Grammar and meaning, 90-115. Cambridge: Cambridge University Press.

Levinson, Stephen C. (2000). Presumptive Meanings: The Theory of Generalized Conversational Implicature. Cambridge MA: MIT Press. 
Omazić, Marija. (2005a). Introduction: Why, What and How in phraseology. Jezikoslovije 6 (1), 1-5.

Omazić, Marija. (2005b). Cognitive linguistic theories in phraseology. Jezikoslovije 6 (1), 37-56.

Pawley, Andrew \& Syder, Frances H. (1983). Two Puzzles for Linguistic Theory: Nativelike Selection and Nativelike Fluency. In J. C. Richards \& R. W. Schmidt. (eds.). Language and Communication, 191-226. London: Longman.

RHWD $=$ Random House Webster's Unabridged Dictionary. (2001). New York: Random House.

Sánchez López, Elena. (2015). Phraseologization as a Process of Semantic Change. Catalan Journal of Linguistics 14, 159-177. Available at: http://revistes.uab.cat/ catJL/article/view/v14-sanchez.

Sinclair, John. (1991). Corpus, Concordance and Collocation. Oxford: Oxford University Press.

Siyanova-Chanturia, Anna. (2015). On the 'holistic' nature of formulaic language. Corpus Linguistics and Linguistic Theory 11 (2), 285-301. DOI: 10.1515/cllt2014-0016.

Siyanova-Chanturia, Anna \& Martínez, Ron. (2015). The idiom principle revisited. Applied Linguistics 36 (5), 549-569. DOI: 10.1093/applin/amt054.

Telija, Veronika N. et alii (eds.). (1990). Frazeografija v Masinnom fonde russkogo jazyka. Moskva: Nauka.

Telija, Veronika N. (1996). Russkaja fraseologuija. Moskva: Shkola Yazyki russkoj kultury.

Timofeeva, Larissa. (2008). Acerca de los aspectos traductológicos de la fraseología española. Alicante: Universidad de Alicante. Disponible en: http://rua.ua.es/ dspace/handle/10045/7707.

Timofeeva, Larissa. (2009). La desautomatización fraseológica: un recurso para crear y divertir. In J. L. Jiménez Ruiz \& L. Timofeeva. (eds.). Estudios de Lingüistica: Investigaciones lingüisticas del siglo XXI, 249-271. Alicante: Universidad de Alicante.

Timofeeva-Timofeev, Larissa. (2012). El significado fraseológico. En torno a un modelo explicativo y aplicado. Madrid: Ediciones Liceus.

Timofeeva-Timofeev, Larissa. (2013). En torno al tratamiento lexicográfico de la fraseología humorística. RLA 51 (1), 127-151.

Timofeeva-Timofeev, Larissa. (2016). Children Using Phraseology for Humorous Purposes: The Case of 9-to-10-year-olds. In L. Ruiz-Gurillo. (ed). Metapragmatics of Humor: Current Research Trends, 275-300. Amsterdam: John Benjamins. DOI: 10.1075/ivitra.14.14tim.

Timofeeva-Timofeev, Larissa. (in preparation). Sobre las malvas, las larvas y otras especies fraseológicas. 
Timofeeva-Timofeev, Larissa. \& Vargas-Sierra, Chelo. (2015). On Terminological Figurativeness: From Theory to Practice. Terminology 21 (1), 102-125. DOI: 10.1075/term.21.1.05tim.

Verschueren, Jef. (1999). Understanding Pragmatics. London: Arnold; New York: Oxford University Press.

Verschueren, Jef. (2000). Notes on the Role of Metapragmatic Awareness in Language Use. Pragmatics 10 (4), 439-456.

Vinogradov, Viktor. [1947] (1977). Ob osnovnykh tipakh fraseologuicheskikh edinits v russkom jasyke. In V. Vinogradov. Izbrannyje trudy. Leksikologuija y leksikografia, 140-161. Moskva: Nauka.

Wray, Alison. (2002). Formulaic Language and the Lexicon. Cambridge: Cambridge University Press.

Wray, Alison. (2008). Formulaic Language: Pushing the Boundaries. Oxford: Oxford University Press.

Zuluaga, Alberto. (1980). Introducción al estudio de las expresiones fijas. Frankfurt am Main: Peter Lang. 